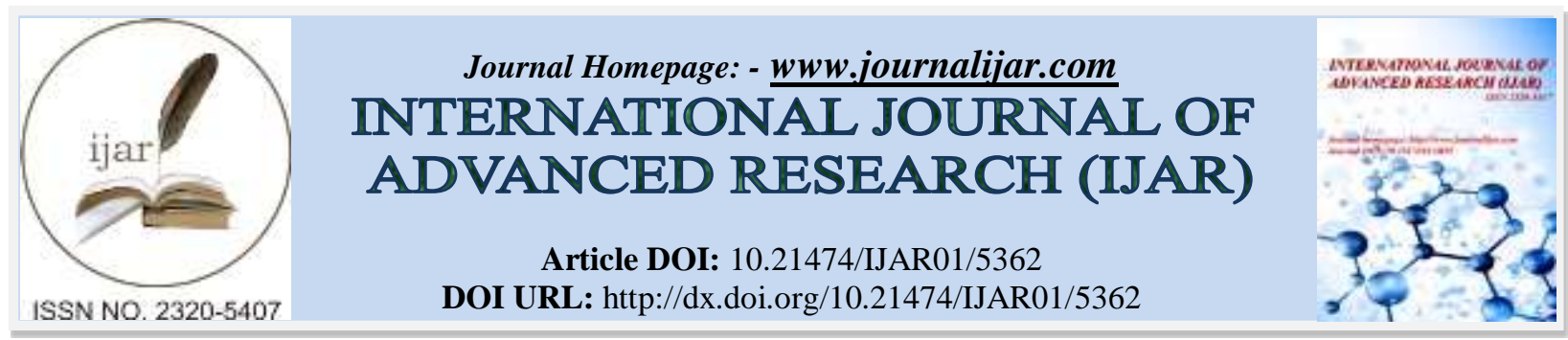

RESEARCH ARTICLE

\title{
STUDY OF PB(II) AND FE(III) METAL CATIONS ADSORPTION INTO $P$-TERT- BUTYLCALIX[4]ARENE AS ADSORBENT: KINETIC ADSORPTION.
}

\author{
Busroni ${ }^{1}$, Siswanta. $\mathbf{D}^{2}$, Santosa. S. $\mathbf{J}^{2}$ and Jumina ${ }^{2}$. \\ 1. Departement of Chemistry, Faculty of Matematics and Natural Sciences, University of Jember, Indonesia. \\ 2. Departement of Chemistry, Faculty of Matematics and Natural Sciences, Gadjah Mada University, Yogyakarta.
}

\section{Manuscript Info}

Manuscript History

Received: 08 July 2017

Final Accepted: 10 August 2017

Published: September 2017

Key words:-

tb-calix[4]arene, adsorbents, isotherms, adsorption capacity, adsorption energy.

\begin{abstract}
This research explain the study about compound of 5,11,17,23-tetra(tButyl)-25,26,27,28-tetrahidroxycalix[4]arene (TBCA) that will be used as adsorption material for heavy metal cations. Adsorption using immersion method with variations such as the value of acidity $(\mathrm{pH})$, time of exposure and initial concentration of metal cations have been conducted. The results of each investigation showed that the optimum $\mathrm{pH}$ of adsorption was at $\mathrm{pH}=5$ for metal cations of $\mathrm{Pb}$ (II) and $\mathrm{Fe}$ (III). The observation results showed the optimum time exposure of cation adsorption of $\mathrm{Pb}(\mathrm{II})$ and $\mathrm{Fe}(\mathrm{III})$ was 90 minutes. Study about kinetic adsorption of $\mathrm{Pb}$ (II) metal cations of the adsorbent refered the Ho kinetic model, pseudo second order with rate constant of adsorption $143 \times 10^{-3} \mathrm{~g} \cdot \mathrm{mol}^{-1} \cdot \mathrm{min}^{-1}$ and $\mathrm{Fe}(\mathrm{III})$ refered the Lagergren kinetics model, pseudo first order with the rate constant of $9.21 \times 10^{-3} \mathrm{~min}^{-1}$. The observation of the study showed that the isotherms adsorption for metal cations of $\mathrm{Pb}$ (II) and $\mathrm{Fe}$ (III) refered the pattern trend of Langmuir isotherm models. The value of the optimum capacity for metal cation adsorption $\mathrm{Pb}$ (II) and $\mathrm{Fe}(\mathrm{III})$ each was $128.46 \mathrm{mg} / \mathrm{g}$ and $156.09 \mathrm{mg} / \mathrm{g}$ respectively. Adsorption energy for $\mathrm{Pb}$ (II) and $\mathrm{Fe}(\mathrm{III})$ was $5.81 \mathrm{k.J} / \mathrm{mol}$ and $7.01 \mathrm{~kJ} / \mathrm{mol}$, respectively.
\end{abstract}

Copy Right, IJAR, 2017,. All rights reserved.

\section{Introduction:-}

The existence of the metal cations can endanger human health as heavy metals if enter into the body, because the heavy metals are toxic/poison. Heavy metals are chemical elements with a specific gravity greater than $5 \mathrm{~g} / \mathrm{cm}^{3}$ that located in the lower right corner of the periodic table system. Iron or Ferrum $(\mathrm{Fe})$ is a silvery-white metal, clay, and can be formed. It has been conducted a study of adsorption of metal cations Fe(III) in aqueous systems using zeolite, in the determination of adsorption of metal cations $\mathrm{Fe}^{+3}$ performed at $\mathrm{pH}$ area between 1-6 [1]. Lead was widely used in the paint factory, fuel, battery industry and ammunition bullets. Lead is toxic which very influenced toward children, because the paint is widely used in residences. If the metal contains in the blood up to $10 \mathrm{mg} / \mathrm{mL}$, it can cause illness symtoms and $\mathrm{Pb}(\mathrm{II})$ concentrations in the water does not depend on the season, but on the depth. Lead ions contained in the water can get into the body of the fish and other aquatic animals [2]. Siswanta research resulted that the adsorbent Calix[4]resorcinarene, hybrid or Calix[4]resorcinarene-chitosan and chitosan can be applied to eliminate the $\mathrm{Pb}(\mathrm{II})$ metal ions. The results of the investigation explained that the value of adsorption capacity was Calix[4]resorcinaren > Chitosan > Calix [4] resorcinarene-chitosan (hybrid) [3]. Prabawati, reported that it can be synthesized compounds of p-t.butyl-37-monoallyloxy-38,39,40,41,42-pentahidroxycalix[6]arene and p-t.butyl- 
37,40-diallyloxy-38,39,41,42-tetrahidroxycalix[6]arene then each of them was treated by polymerization reaction in order so can be obtained poly-monoallyloxycalix[6]arene compound [PMK(6)H]arene and polydiallyloxycalix[6]arene compound $[\mathrm{PDK}(6) \mathrm{H}]$ arene and was applied to study the adsorption kinetics for $\mathrm{Cu}(\mathrm{II})$, $\mathrm{Cd}(\mathrm{II})$, and $\mathrm{Cr}(\mathrm{III})[4,5,6]$. Calixarene can form complexes with the type of aromatic compounds in a polar solvent non water. Compounds calixaren with basketball shape has high potential as a host-guest. In this case, this calixarene compound capable to clamp the organic molecules. Calixarene compounds can be synthesized and derivatized at the "Lower Rim", therefore the part of upper rim calixarene rim is slow to develop [7]. Some type of adsorbent has been used to eliminate or reduce heavy metals, i.e. Poly-Calix[4]arene-Crown-6 $[8,9,10,11]$, benzyloxycalix[4]arene [12], Calix[4]Resorcine [13,14], calixarene derivative [15], Calix[8] arene Derivative. [16], Bisazocalix[4]arene [17], t-butylcalix[4]arene derivatives [5]. Many attempts have been made to reduce the concentration of heavy metal cations, and guided by a number of facts about the consequences caused by the presence of heavy metal cations, the effort was made to reduce the concentration, especially in the waters.

\section{Research Methods:-}

\section{Materials and Instrumentation}

Material: Compounds tb-Calix[4]arenes were synthesized following the reported procedure [18], aquabides / aquadimeneral (Lab. Organic FMIPA-UNEJ), $\mathrm{FeCl} 3, \mathrm{~Pb}$ (NO3) 2, another reagent (Merck branded) was used without special treatment.

Instrumentation: PRESTIGE 21 Shimadzu FTIR-spectrometer with KBr, Electrothermal Digital Point, H-NMR AGILENT Varian $400 \mathrm{MHz}$, AAS Buck Scientific.

\section{Methods}

\section{Effect of pH}

As many as $10 \mathrm{~mL}$ sample solution with a $\mathrm{pH}$ of 3;4;5; 6 was put in a $15 \mathrm{~mL}$ glass bottles that have been filled by $5 \mathrm{mg}$ adsorbent. Each bottle was stirred using a magnetic stirrer for 3 hours, filtered with filter paper then the residue metal cation was determined using filtrate which was analyzed using atomic absorption spectrophotometer (AAS) to determine how the cations were adsorbed.

\section{Effect of time exposure:-}

Cation solution of $\mathrm{Pb}(\mathrm{II})$ and $\mathrm{Fe}(\mathrm{IIII})$ based on observation at optimum $\mathrm{pH}$ of 5 was prepared about $10 \mathrm{~mL}$ in amount and inserted into a $15 \mathrm{~mL}$ vial glass which was filled with adsorbent $10 \mathrm{mg}$ in each. All of the test solution was stirred using a magnetic stirrer with a time variation of 10, 20, 30, 90, 180, 240 minutes. Then the solution was filtered and the filtrate was analyzed by AAS.

\section{Effect of adsorbate concentration:-}

Each sample solution of metal cations $\mathrm{Pb}$ (II) and $\mathrm{Fe}$ (III) was prepared about $10 \mathrm{~mL}$ amount at optimum $\mathrm{pH}$ with various concentrations of $8,16,20,24,30 \mathrm{ppm}$ and put in a $15 \mathrm{~mL}$ glass bottle sizes that have been filled adsorbent $10 \mathrm{mg}$. All solutions were stirred with optimum time. Then it was filtered and each filtrate was analyzed by AAS.

\section{Results and Discussion:- Effect of pH:-}

Metal cation adsorption capacity was very dependent on the amount of the $\mathrm{pH}$ solution. At low $\mathrm{pH} / \mathrm{very}$ acidic condition, the number of $\mathrm{H}^{+}$ions became high and it resulting in the $\mathrm{OH}$ groups protonation. Then the property of the $\mathrm{OH}$ group became positively charged and the ability as a ligand will be reduced. The positive charge on the adsorbent tb-calix[4]arenes caused repeling process between $\mathrm{H}^{+}$with metal ions, so that the adsorption value became small. Adsorption increased in line with the increasing of $\mathrm{pH}$ value around $\mathrm{pH}$ 5. As shown in Figure 1, it exhibited that the adsorption of metal cations $\mathrm{Pb}$ (II) and $\mathrm{Fe}$ (III) to tb-calix[4]arene depended on the $\mathrm{pH}$ factor. Both of metal cation $\mathrm{Pb}(\mathrm{II})$, and $\mathrm{Fe}(\mathrm{III})$ were maximum adsorpted at $\mathrm{pH} 5$ with $\mathrm{Pb}(\mathrm{II})$, and $\mathrm{Fe}(\mathrm{III})$ adsorbed value was $10.52 \mathrm{mg} / \mathrm{g}$ and $14.18 \mathrm{mg} / \mathrm{g}$. respectively (Fig. 1). 


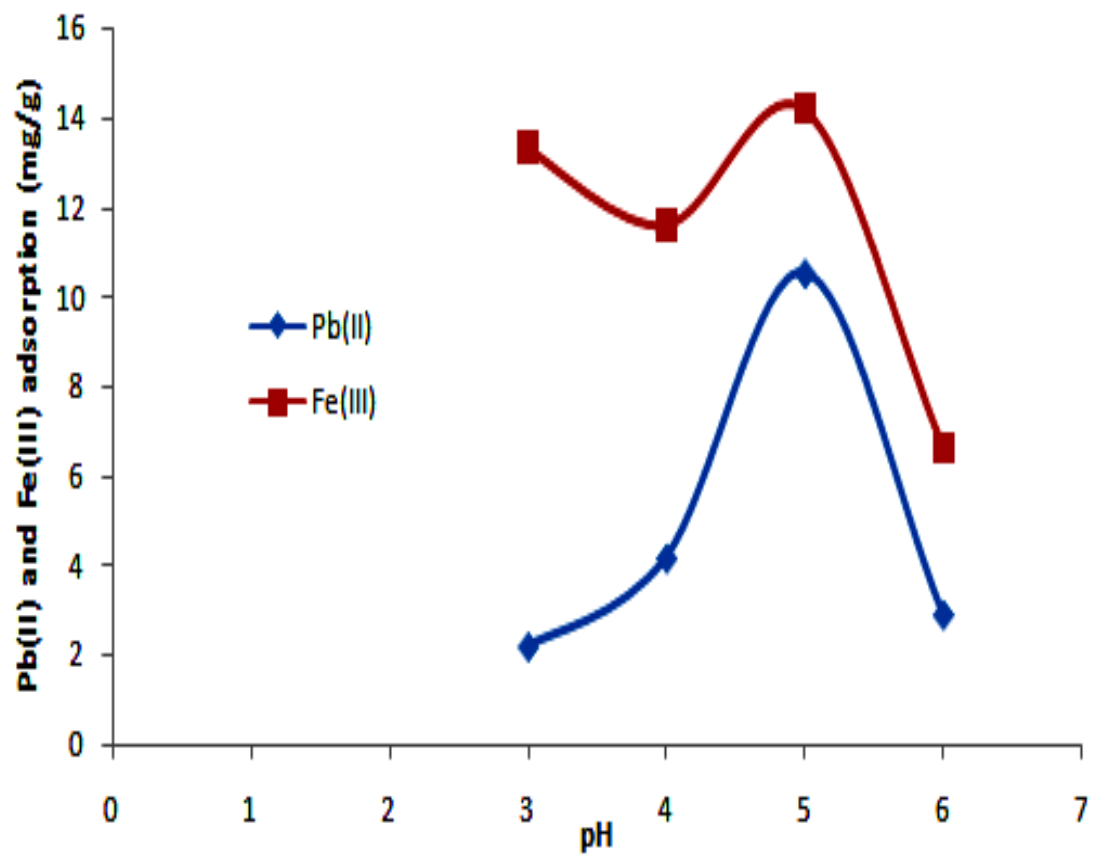

Fig.1:- Effect of $\mathrm{pH}$ on the $\mathrm{Pb}(\mathrm{II})$, and $\mathrm{Fe}(\mathrm{III})$ cations adsorption by p-t-Butylcalix[4]arene (TBCA)

\section{Effect of exposure time:-}

The adsorption kinetics of $\mathrm{Pb}(\mathrm{II})$ and $\mathrm{Fe}$ (III) cations into p-t-Butylcalix[4]arenes was presented in Fig. 2. According to the investigation results, the optimum exposure time of metal cations of $\mathrm{Pb}(\mathrm{II})$ and $\mathrm{Fe}(\mathrm{III})$ was 90 minutes, with the cation concentration that can be adsorbed was $12.69 \times 10^{-2} \mathrm{mmol} / \mathrm{g}$ and $34.77 \times 10^{-2} \mathrm{mmol} / \mathrm{g}$ respectively. The measurement of adsorption kinetic rate can be determined by using the interaction time required to reach a state of equilibrium adsorption. The used general parameters to study the adsorption rate was reaction rate cosntant (k). From Table 1, it can be studied that the adsorption kinetics model reffered to first order Lagergren kinetics model, and second order kinetic model [19, 20, 21]. The results of calculations were presented in Table 1.

Table 1:- Adsorption Kinetic Models

\begin{tabular}{|c|c|c|c|c|}
\hline \multirow[t]{2}{*}{ Kinetic Models } & \multicolumn{2}{|l|}{$\mathrm{Pb}(\mathrm{II})$} & \multicolumn{2}{|c|}{$\mathrm{Fe}(\mathrm{III})$} \\
\hline & $\mathrm{R}^{2}$ & $\mathrm{k}$ & $\mathrm{R}^{2}$ & $\mathrm{k}$ \\
\hline $\begin{array}{l}\text { Pseudo Orde 1 (Lagergren) } \\
\left(\mathrm{q}_{\mathrm{e}}-\mathrm{q}_{\mathrm{t}}\right)=\log \left(\mathrm{q}_{\mathrm{t}}\right)-\frac{\mathrm{k}_{1}}{2,303} \mathrm{t}\end{array}$ & 0,836 & $\begin{array}{l}6,91 \times 10^{-3} \cdot( \\
\left.\text { minute }^{-1}\right)\end{array}$ & 0,971 & $\begin{array}{l}9,21 \mathrm{x} \\
\left(\text { minute }^{-1}\right)\end{array}$ \\
\hline $\begin{array}{l}\text { Pseudo Orde } 2(\text { Ho) } \\
\mathbf{t k}_{2} \mathbf{q e}^{2}=\frac{\mathbf{q e}_{\mathrm{e}} \cdot \mathbf{q}_{\mathrm{t}}}{\left(\mathbf{q}_{\mathrm{e}}-\mathbf{q}_{\mathrm{t}}\right)}\end{array}$ & 0,957 & $\begin{array}{l}143 \times 10^{-3} \\
\text { (g.mg }{ }^{-1} \cdot \text { minute } \\
\end{array}$ & 0,928 & $\begin{array}{l}16 \times 10^{-3} \\
\left(\begin{array}{l}\text { g.mg } \\
\text { minute }\end{array}{ }^{-1}\right)\end{array}$ \\
\hline
\end{tabular}




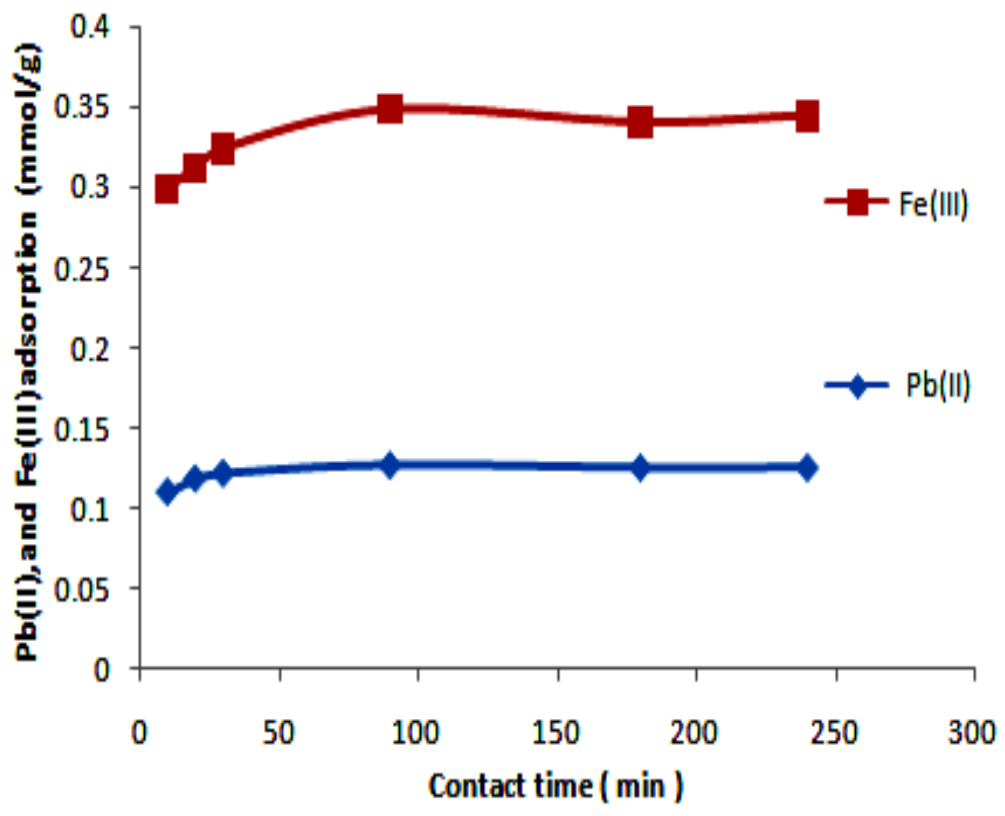

Fig. 2:- the effect of time exposure on removal of $\mathrm{Pb}(\mathrm{II})$ and $\mathrm{Fe}(\mathrm{III})$ cations by p-t-Butylcalix[4]arene (TBKA) adsorption
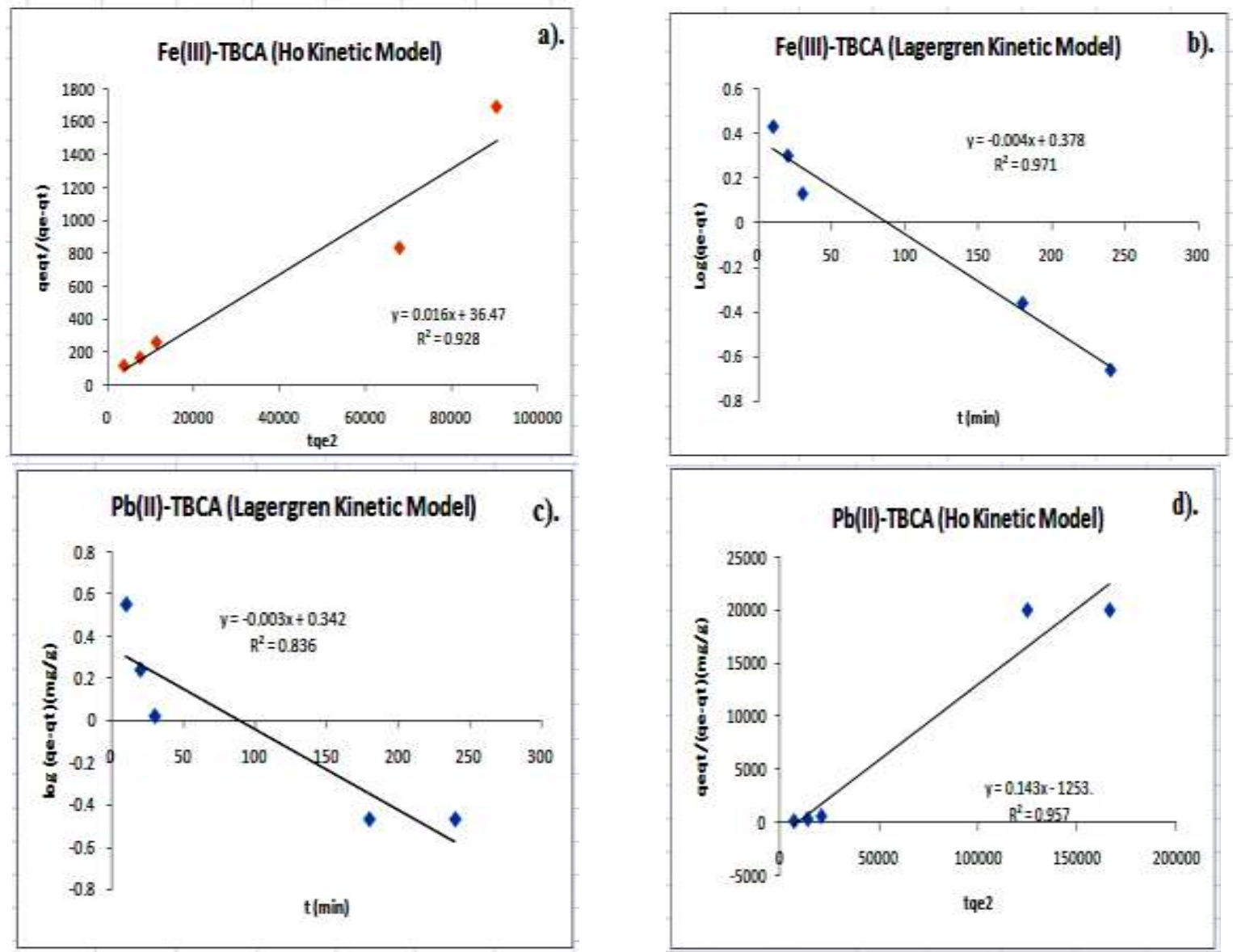

Fig. 2:- (a; b; c; and d) Pseudo first order kinetic for $\mathrm{Pb}(\mathrm{II})$, and $\mathrm{Fe}(\mathrm{III})$ adsorption on the TBCA and Pseudo second order kinetic for $\mathrm{Pb}(\mathrm{II})$, and $\mathrm{Fe}(\mathrm{III})$ adsorption on the TBCA 
Based on the data analysis Table 1 and Fig. 2 (a, b, c, and d), it showed that the Ho kinetics model had higher linearity curve than the Lagergren kinetic model against metal cation of $\mathrm{Pb}(\mathrm{II})$. Otherwise, $\mathrm{Fe}(\mathrm{III})$ cation had higher linearity of Lagergren kinetic model rather than Ho kinetic model. Cation adsorption rate constant for $\mathrm{Pb}$ (II) can be determined based on the kinetic model of Ho as a slope, the value was $143 \times 10^{-3}\left(\mathrm{~g} \cdot \mathrm{mg}^{-1} \cdot \mathrm{min}^{-1}\right)$. The adsorption constant rate of $\mathrm{Fe}(\mathrm{III})$ can be determined through Lagergren kinetic model approach as slope and the value was $9.21 \times 10^{-1}\left(\mathrm{~min}^{-1}\right)$.

\section{Kinetics Adsorption}

The effect of cation concentration of $\mathrm{Pb}$ (II) and $\mathrm{Fe}(\mathrm{III})$ versus the concentration of adsorbed metal cation was exhibited in Fig.3. Observation at low concentration (about 8 ppm) showed little adsorbed metal cations, it happened because the metal cation was available in small amount. Then the amount of adsorbed metal cations increased significantly in accordance with the increase in the concentration of metal cations.

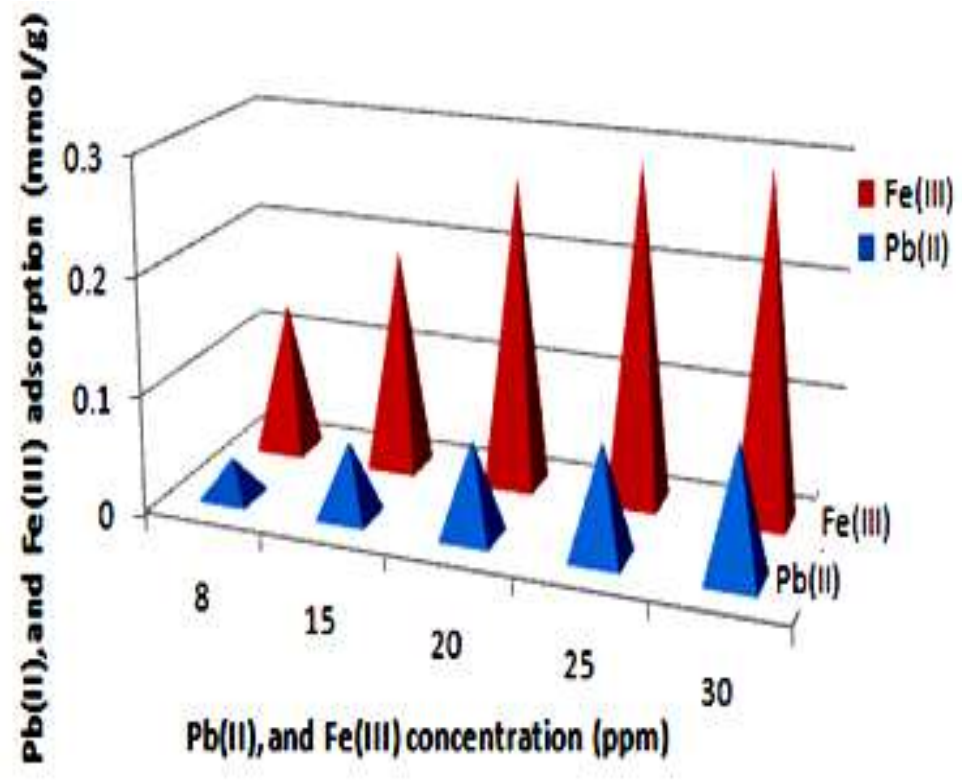

Fig. 3:- Effect of adsorbate concentrations on the $\mathrm{Pb}(\mathrm{II})$, and $\mathrm{Fe}(\mathrm{III})$ by p-t-Butylcalix[4]arene (TBCA)

\section{Isotherms Adsorption:-}

Isotherm adsorption can be determined using the data obtained from the value of the adsorbed metal cations on the variation of metal cations initial concentration (data in Fig. 3). Isotherm equation used was the equation of Langmuir and Freundlich

$$
\begin{aligned}
& \text { Langmuir Equation: } \quad \frac{\mathrm{Ce}}{\mathrm{q}_{\mathrm{e}}}=\frac{1}{\mathrm{~K} \cdot \mathrm{X}_{\mathrm{m}}}+\frac{\mathrm{Ce}}{\mathrm{X}_{\mathrm{m}}}
\end{aligned}
$$

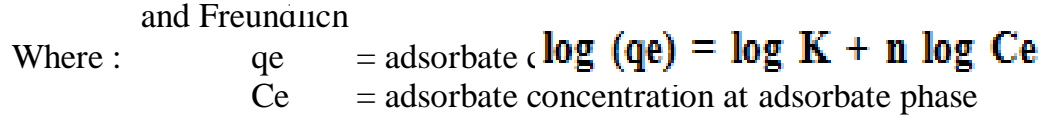

$$
\begin{aligned}
& \mathrm{Xm}=\text { maximum adsorption capacity } \\
& \mathrm{K} \text { = equilibrium constant / intercept } \\
& \mathrm{n} \quad=\text { slope }
\end{aligned}
$$

Indications which were obtained from Langmuir and Freundlich isotherm analysis were presented in Table 2. From Table 2 and Fig. 4 (a, b, c; and d), it can be concluded that each pattern of cation adsorption Pb(II), and Fe(III) refered the model of Langmuir isotherm adsorption. It mean that in the process of adsorption occured in a single layer (monolayer). Further it can be assumed that the maximum adsorption occured during interaction between all of the active site ( $\mathrm{OH}$ groups) adsorbents and the adsorbate of metal cations $\mathrm{Pb}$ (II) or $\mathrm{Fe}$ (III) by forming the monolayer, with the adsorption energy value between cations $\mathrm{Pb}(\mathrm{II})$, and $\mathrm{Fe}(\mathrm{III})$ was $5.81 \mathrm{~kJ} / \mathrm{mol}$ and $7.01 \mathrm{k} \mathrm{J} / \mathrm{mol}$ 
respectively. From Table 2, it showed that the maximum adsorption capacity of $\mathrm{Fe}(\mathrm{III})>\mathrm{Pb}$ (II), this can be explained using the concept $\mathrm{HSAB}$. $\mathrm{Pb}(\mathrm{II})$ was an medium acid while Fe(III) was hard acid because it had small radii and high charge. On the concept of $\mathrm{HSAB}$, medium acid bound with soft acid, while the hard acid bound to a hard base. Active sites on the adsorbent was an $\mathrm{OH}$ group which was a hard base, so $\mathrm{OH}$ groups will be more stable bound to Fe (III) which belonged to the hard acid category. [22].

Table 2:- Indication of isotherm adsorption and its determination from Langmuir and Freundlich

\begin{tabular}{|l|l|l|l|l|l|l|l|}
\hline \multirow{3}{*}{ Metal } & \multicolumn{7}{|c|}{ Indcation of adsorption } \\
\cline { 2 - 8 } & \multicolumn{7}{|c|}{ Langmuir } \\
\cline { 2 - 8 } & $\mathrm{Xm}(\mathrm{mol} / \mathrm{g})$ & $\mathrm{K}(\mathrm{L} / \mathrm{mol})$ & $\Delta \mathrm{G}(\mathrm{k} \mathrm{J} / \mathrm{mol})$ & $\mathrm{R}^{2}$ & $\mathrm{n}$ & $\mathrm{K}(\mathrm{L} / \mathrm{mol})$ & $\mathrm{R}^{2}$ \\
\hline $\mathrm{Pb}(\mathrm{II})$ & 128,46 & 10,21 & 5,81 & 0,971 & 0,330 & 2,652 & 0,628 \\
$\mathrm{Fe}(\mathrm{III})$ & 156.09 & 16,62 & 7,01 & 0,946 & 0,456 & 0,016 & 0,813 \\
\hline
\end{tabular}
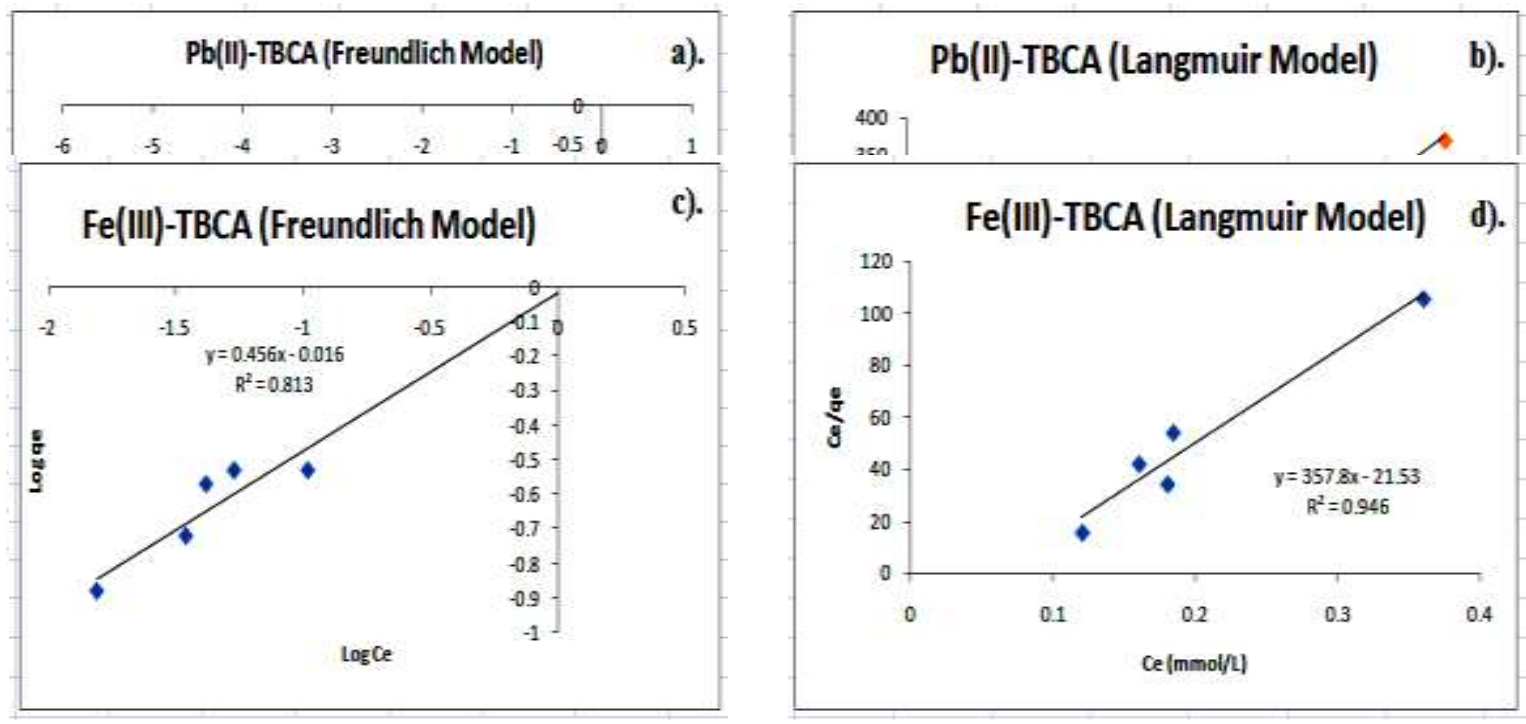

Fig. 4 (a;b;c;and d):- Isotherm Adsorption of Langmuir and Freundlich on $\mathrm{Pb}(\mathrm{II})$, and Fe(III) adsorption of the TBCA

\section{Conclusion:-}

In the process of adsorption of metal cations $\mathrm{Pb}$ (II), and Fe(III) using adsorbent p-t-Butylcalix[4] arenes (TBCA), it refered the Ho kinetics model, pseudo second order and had a value of adsorption rate constant $\mathrm{k}=143 \times 10^{-3}$ ( $\mathrm{g} \cdot \mathrm{mg}^{-}$ $\left.{ }^{1} . \mathrm{min}^{-1}\right)$, further it refered the kinetics model Lagergren, pseudo first order with the value of the adsorption rate constant was $\mathrm{k}=9.21 \times 10^{-3}\left(\mathrm{~min}^{-1}\right)$. From the study of the adsorption isotherm, it indicated that the adsorption process of both $\mathrm{Pb}$ (II) and $\mathrm{Fe}(\mathrm{III})$ cations refered the Langmuir isotherm, with a maximum capacity of cation adsorption of $\mathrm{Pb}(\mathrm{II})$, and $\mathrm{Fe}(\mathrm{III})$ was $128.46 \mathrm{~mol} / \mathrm{g}$ and $156.09 \mathrm{~mol} / \mathrm{g}$ respectively. Adsorption energy for $\mathrm{Pb}(\mathrm{II}) \mathrm{and}$ $\mathrm{Fe}(\mathrm{III})$ was $5.81 \mathrm{k.J} / \mathrm{mol}$ and $7.01 \mathrm{~kJ} / \mathrm{mol}$, respectively.

\section{References:-}

1. Salgado, P., Melin, V., Contresas, D., Moreno, Y., and Mansilla, H.D., 2013, Fenton Reaction Driven by Iron Ligands, J. Chil.Chem. Soc. Vol 58, no.54, Concepcion

2. Roundhill, D. M., 2004, "Strategis for The Removal of Toxic Metal from Soils and Waters, Journal of Chemical Education, “ 81, (2),275-282

3. Siswanta, D., Jumina, Anggraini, M., Mardjan, M.I.D., Mulyono., and Ohto, K., 2016, “ Adsorption Study of $\mathrm{Pb}$ (II) on Calx[4]resorcinarene-Chitosan Hybrid”, International Journal of Applied Chemistry, Vol. 12, Number 1, pp. 11-22

4. Prabawaty, S., Y., Jumina, Santosa, S. J., and Mustofa, 2011, "Synthesis Of Poly-propylcalix[6]arene From p-tButylphenol As Adsorbent For Cr(III) Metal Ion”, Indo. J. Chem. 11, (1), 37-42

5. Prabawaty, S., Y., Jumina, Santosa, S. J., and Mustofa, Ohto, K., 2012, “ Study On The Adsorption Properties Of Novel calyx[6]arene Polymer For Heavy Metal Cations”, Indo. J. Chem. 12, (1), 28-34 
6. Prabawati, S.Y., Jumina, Santosa, S. J., and Mustofa, 2014, The Synthesis, Characterization and Properties of Calix[6]arene-Based Polymer, Int'l. J. of Adv. In Chem. Engg., \& Biological Sciences (IJACEBS), Vol. 1, Issue 1, ISSN 2349-1507 EISSN 2349-1515

7. Tung C. H., and Ji, H. F., 1997, A Novel Host Molecule p-[1-(4-hidroxyphenyl)-1-methylethyl]-calix[8]arene. Synthesis and Complexation Properties in non-aqueous Polar Solution, J. Chem. Soc., Perkin Trans 2, 185-188

8. Kusumaningsih, T., Jumna, Siswanta, D., Mustofa, Ohto, K., and Kawakita, H., 2012, Synthesis of Poly-Tetrap-Allylcalix[4]arene tetra acetic acid Adsorbent for $\mathrm{Cr}(\mathrm{III})$ and $\mathrm{Pb}$ (II) Metal ions, Internatiol Journal of Technology, 2, 93-102

9. Ulewicz, M., Bochenska, M., Lesinska, U., Walkowiak, W., 2005, “Studies On Removal Of Zn(II), Cd(II), and $\mathrm{Pb}$ (II) Ions In Polymer Inclusion Membrane Transport With Calix[4]-Crown-6 Derivatives “, Physicochemical Problems of Mineral Processing, 39, 107-116

10. Yang, F. F., Zhao, X., Huang, C. Y., Guo, H., Y., Zheng, S. N., Peng, Q., 2006, Synthesis and Complexation Properties of Novel Biscalixarene Composed o. Calix[4]arene and Thiacalix[4]arene Subunits, Chinese Chem. Latters, Vol. 17, No. 8, pp 1029-1032Yang, F. F., Huang, Z. S., Zhang. X. Y., and Guo, H. Y., 2010, “ Thiacalix[4]amido-based Netty Polymer: NovelSorbent for Heavy Metal Cations and Derivatives of Aniline", Iranian polymer Journal, 19(4), 309-318 Gharib, F., Ganjali, S.T., Eslamipanah, M., Mazooji, R., and Ebrahimi, S., 2006, "Complexation of Di and Tetra-Benzyloxy Ether Derivatives of Calix[4]arene With Alkali Metal Cations “, Acta Chim. Slov., 53, 427-415

11. Kesuma, E.D., Jumina, Ohto, K., and Siswanta, D., 2016, “ Synthesis of C-4-Allyloxy-3Methoxyphenylcalix[4]resorcinarene from Vanilin and Its Application as Adsorbent of $\mathrm{Pb}$ (II) Metal Cation ", Oriental Journal of Chemistry, Vol. 32, No. 2, Pg. 769-775

12. Vyas, D.J., Makwana, B. A., Bhatt, K. D., Jain, V. K., 2013, "Octa-O-Methoxy Resorcin[4]arene Amberlite XAD-4 Polymeric Chelating Resin for Solid Phase Extraction, Preconcentration, Separation and Trace Determination of $\mathrm{Ni}(\mathrm{II}), \mathrm{Cu}(\mathrm{II}), \mathrm{Zn}(\mathrm{II})$ and $\mathrm{Cd}(\mathrm{II})$ Ions, "American Journal of Analytical Chemistry, 4, 238251[4=19] Ho, Y.S. dan McKay, G., 1999, Pseudo-second Order Model for sorption Processes, Elsevier, 34, 451-465

13. Maming, 2008, “ Transpor $\mathrm{Cr}(\mathrm{III}), \mathrm{Cd}(\mathrm{II}), \mathrm{Pb}(\mathrm{II})$, dan $\mathrm{Ag}(\mathrm{I})$ melalui membrane cair ruah yang mengandung turunan karboksilat, ester, dan amida p-tert.butilkaliks[4]arena sebagai pengemban ion, Disertasi Doktor Pascasarjana, Universitas Gadjah Mada, YogyakartaQureshi, I., Memon, S., and Yilmas, M., 2008, “Extraction and Binding Efficiency of Calix[8]arene Derivative Toward Selected Transition Metals", Pak. J. Anal. Environ. Chem., Vol. 9, No. 2, 96-100

14. Elcin, S., Karakus, O. O., Kara, I., Deligos, H., 2015, "Synthesis and structural caharacterization of bisazocalix[4]arene with melamine: Metal ion extraction studies, " Journal of MolecularLiquids, " 202, 134-140

15. Gutsche, C.D and M. Iqbal, 2005, “ Organic Synthesis “, Inc. All Rights Reversed, Coll. 8, 75

16. Ho,Y.S.and McKay, G., 1999, Pseudo-second Order Model for sorption Processes, Elsevier, 34, 451-465

17. Ho, Y.S., 2004, Citation Review of Lagergren Kinetic Rate Equation on Adsorption Reaction, Scientometrica, $59,1,171-177$

18. Rosas, C. C., 2010, Synthesis and Application of Manganese Dioxide Coated Magnetite for Removal of Metal Ions from Aqueous solutions, Dissertation Doctor

19. Pearson, R.G., 1963, Hard and Soft Acid Bases, J. Am.Soc., 85, 3533-3539 